Issues in theory and methods of teaching foreign languages.

Проблеми теорії і методики навчання іноземних мов

УДК 811.11

https://doi.org/10.31548/philolog2021.02.126

\title{
FOREIGN LANGUAGE COURSES THEMES FOR THE SENIOR STUDENTS IN SPECIALTY "GEODESY AND LAND PLANNING"
}

\author{
K. H. YAKUSHKO, PhD in Pedagogy, Senior lecturer, \\ National University of Life and Environmental Sciences of Ukraine \\ E-mail: vukladach@ukr.net \\ http://orcid.org/0000-0001-6977-8441 \\ A. V. POLISHCHUK, Senior lecturer, \\ National University of Life and Environmental Sciences of Ukraine \\ E-mail: linapolischuk@nubip.edu.ua \\ http://orcid.org/0000-0002-8995-7911 \\ L. V. BEREZOVA, PhD in Psychology, Associate Professor, \\ National University of Life and Environmental Sciences of Ukraine \\ E-mail: berezova@nubip.edu.ua \\ http://orcid.org/0000-0002-8443-8442
}

\begin{abstract}
Nowadays it is paid attention to the problem of thematic content of professional purpose English language curriculum in general meaning or with the business emphasis or as a course for enrolling to Master's degree course. The purpose of article is the description of foreign language courses for specialty "Geodesy and Land Planning" concerning either the further stage of the bachelor's degree program studying or concerning previous stage of the master's degree program studying as well as comparative analysis of adequate syllabuses on the basis of pedagogical observation during 2019/2020 educational process. The result of investigation lays in 8 conclusions: 1) foreign language course for the master's degree freshmen's program is mainly aimed to develop business speech with addition of forming general communicative, professional and scientific communicative skills for all students of all forms of studying according to specialty "Geodesy and Land Planning"; 2) foreign language course for the second year bachelor's degree program is mainly tending to prepare students to pass entrance unified exam to enroll magistracy as well as repeating basic grammar, special terms and communicative clichés, it is aimed to be studied only by the advanced group students who had joint the community of future land managers after graduation from the profile colleges and who did not learn foreign language on the first course of studying at the Faculty of Land Management within the National University of Life and Environmental Sciences of Ukraine; 3) thematic filling of foreign language course for the second year bachelor's degree advanced group students in land management is similar to some topics to be studied by bachelor's degree senior students of other specialties too exampling specialty "Forestry and Horticulture" or "Mechanical Engineering" as well as the fourth-year students of specialty "Geodesy and Land Planning" as the future entrants of magistracy; 4) foreign language course for the second year bachelor's degree students lasts only one the fourth semester with the planned two or one period a week according to the order of week is seemed to be aimed to update self-studying activity concerning familiarization with the demands for entrance unified foreign language exam passage and adequate training exercises activities; 5) the foreign language course for the master's degree program freshmen lasts during two semesters numbering two constant periods a week in order to get acquainted with foreign language environment in details to master and to improve advanced general communicative professional and scientific speech skills of the entrant to graduate school, of active participant of scientific conferences and businessman-clerk; 6) there are similar demands to fix and to represent the studying results during preparation to the attestation exam on the last lessons: to know basic questions and answers according to the course content, to know the structure of examination card, to know the stages of attestation exam, to be able to apply the got knowledge on practice and to deal with e-learn testing, be able to archive the results of works in the adequate folder; 7) in some cases there are similar types of lesson activities like noting unknown items, preparation, sending and oral defense of practical works, individual tasks, presentations, essays, participation in game, dialogues e-learn testing, etc.; besides, the above named activities the second year students deal with $\epsilon B I$ workbooks filling, the work with $\epsilon B I$ manual and concluding own vocabulary too, such additional activities for the master degree students are writing annotations, theses, stand reports, business letters, etc.; 8) the material for the master's degree course is placed on the National University's of Life and Environmental Sciences of Ukraine Moodle platform as an electronic studying course "Business English course for Geodesy and Land Planning" but course for the second year bachelors is divided into two blocks occupying electronic studying course "English course for Geodesy and Land
\end{abstract}

(C) K. H. Yakushko, A. V. Polishchuk, L. V. Berezova

«International journal of philology» | «Міжнародний філологічний часопис» Vol. 12, № 2, 2021 
Issues in theory and methods of teaching foreign languages.

Проблеми теорії і методики навчання іноземних мов

Planning" and "English Course for Advanced Mechanical Engineers". Perspectives of further investigation is the description of results of the further pedagogical observations to reveal gaps within the above named content curriculum and regarding the expediency of the unification of two blocks for second year students into one special block.

Key words: comparison, thematic filling, semester content, syllabus of foreign language course studying, second-year students, bachelor's advanced group, master's course first stage, geodesy and land planning.

Introduction. In the modern society it's a need to pay attention to the problem of thematic content of professional purpose English language curriculum in general meaning or with the business emphasis or as a course for enrolling to master's degree course basing upon the results of pedagogical experiment within concrete specialty and educational establishment in general and concerning bachelor's degree program second year advanced group students and master's degree program first year all groups students.

Resent researches and publications. The background of the research is the familiarization with the theoretical investigations by I. Grabovska in the aspect of searching topicalizing questions [2], general he guidelines to conclude syllables by O. Botvinko-Botiuk [1] as well as theoretical [3], and practical recommendations to include the development of students' foreign language communicative skills [4] into curricula contents involving concrete purpose of students' studying. Besides, the practical part of investigation based upon our elaborated electronic courses to admit the achieved practical results either in professional terms knowledge [6] and conversational phrases application [8] or preparation to the general entrance foreign language exam [5] or general business course skills [7].

The purpose of the article is the description of foreign language courses content for specialty «Geodesy and Land Planning» concerning either the further stage of the bachelor's degree program studying or previous stage of the master's degree program studying as well as comparative analysis of adequate syllabuses on the basis of pedagogical observation during 2019/2020 educational process exampling the students of the Faculty of Land management within the National University of Life and Environmental Sciences of Ukraine.

Data and methods. To reach the purpose the comparative analyzing, the method of linguistic description, semantic and syntactic methods, interpretation method as well as the methods of quantitative or qualitative analyses were introduced. The background included papers concerning studying methodological complex and adequate electronic courses for future bachelors and entrants to magistery and future masters themselves being authorized either by the chairman of the English Department for Technical and Agrobiological Specialties or by the dean of the Faculty of Land Management within the National University of Life and Environmental Sciences of Ukraine in 2019 and 2020. The material for the master's degree course is placed on the National University's of Life and Environmental Sciences of Ukraine Moodle platform as electronic studying course "Business English course for Geodesy and Land planning" but course for the second year bachelors is divided into two blocks occupying electronic studying course "English course for Geodesy and Land Planning" and "English Course for Advanced Mechanical Engineers".

Results. The first semester thematic structure of the foreign language courses for the master's degree freshmen in specialty "Geodesy and Land Planning" was firstly introduced in short symbols titles to simplify comparative analyzing within other tables to represent syllabus.

Thus, we meant such symbols to fill the column about the results of studying for the first semester for master's degree program freshmen as:

1) Result 1: to assimilate the title of university, faculty, specialty, to use CV concluding scheme, to analyze and to improve Block 1 grammar, reading and transliteration rules knowledge gaps to conclude own sentences;

2) Result 2: to distinguish foreign speech while audio listening, to apply creative and drawing skills while poster designing, to improve Block 2 grammar and Internet sources to conclude own sentences, interviewing with employer;

3) Result 3: to know three main thematic blocks for business and personal conversation, be able to answer and to ask questions about personal data, play role as journalist, analyze data and represent statistical conclusions ;

4) Result 4: to know main demands to presentation, be able to elaborate and to represent presentation according to the set requirements to describe native region special features and perspectives to establish business relations in the sphere of land manager's activity;

5) Result 5: to be able to work within Moodle system, automatic testing, to analyze errors to realize next attempts, be able to represent individual tasks in oral interviewing, to react on remarks, to realize work with mistakes and to conclude own sentences without additional supporting materials; 
6) Result 6: to know main statements to represent different communicative intentions, to be able to conclude adequate own sentences, to apply searching skills to determine real life situations concerning professional land manager's activity being tangent to express different communicative intentions, to recognize foreign speech while listening, to detect the most appropriate statements for own communicative needs, combining basic specialized terms and common speech;

7) Result 7: to know the basic types of questions, be able to conclude real life story «Once upon a time ...» and adequate conversational statements being target to the land manager's activity in groups.

Besides, we meant such symbols to fill the column about the studying tasks as a) Task 1: introductional discussion, noting, essay writing, individual tasks fulfillment; b) Task 2: preparing, elearn sending and oral defense of topical practical work; c)Task 3: preparing, e-learn sending and oral defense of topical individual tasks; d)Task 4: preparation and representation of topical presentation; e)Task 5: Moodle e-learn testing.

All above mentioned symbols were introduced into short review to represent the first semester thematic structure of the foreign language courses for the master's degree freshmen in specialty "Geodesy and Land Planning" as following items concerning Module 1" Demands to Presentation, The First Impression, CV structure, Principles of Interviewing": Topic 1 "Introduction"- result 1, task 1; Topic 2 "The First Impression, My Personality in Symbols" - result 2, task 2; Topic 3 "Journalist's Interviewing and Conclusions" - result 3, task 3; Topic 4" The Demands to Presentation - result 4, task 4"; Topic 5 "E-learn Module 1 Test Representing Results of the Module 1 Individual Tasks" - result 3, task 3; Topic 6 "50 Spread Phrases and Basic Land Management Terms in own Speech. Main Communicative Intentions "result 6, task 1; Topic 7 " Project Dialogue" result 7 , task 3 ; Topic $8 "-$ result 5 , task $5 "$.

The next stage of our investigation is the determination of those extra type results and tasks of studying for the first semester for master's degree program freshmen which were not be used earlier but they are in need for the second semester of second year bachelor's degree program. In this case we meant such symbols to add the column about the results of studying for the second semester for master's degree program freshmen as:

1) Result 9: to know main structural components of the scientific stand report, to apply this knowledge to elaborate own stand report being tangent to the topic of land management diploma project paper;
2) Result 10: to know main structural components of business letter and telephone conversation, be able to write invitation to the scientific conference in the accordance with the previous stand report topic, find interesting information about humorous non-standard letters or situations according to the topic «Business Correspondence» and «Telephone Conversation»;

3) Result 11: to know how to conclude the list of actual scientific researches within land management journals, to be able to fulfill different kinds of reading and translation, to know the structure of annotation, to be able to conclude own summary;

4) Result 12: to know the structural components of theses, to be able to conclude the list of previous and the planned conferences concerning land management branch, to be able to write own theses;

5) Result 13: to know the structure of examination card, the demands to attestation and its stages, be able to review whole course items, the work with mistakes correction;

6) Result 14: to know lexical and grammar system of text «Land Manager's Major», to analyze and to recognize basic land management terms applying them in own statements and search additional adequate information;

7) Result 15: to know the demands to $\epsilon B I$ entrance exam, to train exercising testing of some adequate $\epsilon B \mathrm{BI}$ workbooks or adequate manual with evidence of choice variants.

Besides, we distinguished such symbols to add the items about the tasks of studying for the second semester for master's degree program freshmen as a) Task 9: the elaboration of stand report; b) Task 10: writing of business letter, concluding telephone conversation; c) Task 11: concluding lists, theses writing; d) Task 13: to archive the results of works in the adequate folder; e) Task 14: concluding vocabulary and crosswords; f) Task 15: group discussion, real life game, dialogues, individual tasks performing.

The second semester thematic structure of the foreign language courses for the master's degree freshmen in specialty "Geodesy and Land Planning" according to the Module 3 "Conference Report, Business Letter and Telephone Conversation" may be reviewed in such shortened statements as Topic 9 "Stand Poster Report "result 9, task 9; Topic 10 "Business Letter. Business Telephone Conversation" - result 10, task 10; Topic 11 "Elearn Module 3 Test. Representing Results of the Module 3 Individual Tasks" - result 5, task 5; Topic 12 "Land Management Journals. Summary result 11, task 9"; Topic 13 "Scientific Conferences. Theses" - result 12, task 11; Topic 14 "E-learn module 4 Test. Representing Results of the Module 4 Individual Tasks" - result 5, task 5; Topic 15 "Preparation to Exam" - result 1, task 13. 
The similar results and task would do to fill up the columns of the adequate content structure table concerning second year bachelor's degree students too. These results may be observed in reviewing of the fourth semester thematic structure of the foreign language course for the bachelor's degree second year advanced group students in specialty "Geodesy and Land Planning": Topic 1" Introduction " - result 1, task 1; Topic 2 "A Land Manager's Major"- result 14, task 14; Topic 3 "ЄBI demands in 4 Workbooks" result 15, task 15", Topic 4 "Representing Results of the Module 1 Individual Tasks"- result 5, task 1; Topic 5 "E-learn Module 5 Testing(grammar and specialty)" - result 5, task 5; Topic 6 "Family and Relationship. People and Society. Home.School" - result 15, task 15; Topic 7 "Work. Money. Healthy Living. Travel and Tourism - result 15, task 15"; Topic 8 "Culture and free Time. Sport. Science and Technology. Nature and Environment" - result 15, task 15; Topic 9 "The Demands to Presentation"- result 4, task 3; Topic 10 "Representing Results of the Module 2 Individual Tasks" - result 5, task 5", Topic 11 "Module 2 Testing"- result 3, task 5; Topic 12 "Preparation to Exam" - result 13, task 13.

Discussion. The investigation is either related to the general recommendations to fill the thematic structure of foreign language courses by I. Grabovska, L. Berezova or future land managers'foreign language course themes and types of activities by K.Yakushko by O. BotvinkoBotiuk being fixed in adequate electronic courses. The result of investigation lays in 5 conclusions: 1) foreign language course for the master's degree freshmen's program is mainly aimed to develop business speech with addition of forming general communicative, professional and scientific communicative skills for all students of all forms of studying according to specialty "Geodesy and Land Planning"; 2) foreign language course for the second year bachelor's degree program is mainly tending to prepare students to pass entrance unified exam to enroll magistracy as well as

\section{References}

1. Botvinko-Botiuk, O. M. (2020). Sylabus navchalnoi dystsypliny "Inozemna mova profesijnoho spilkyvannia (anglijska)" dlia zdobuvachiv vushchoi osvity, yaki navchajutsia za osvitno-profesijnoju programoju" Zemleustrij ta kadastr", spetsialnist 193 "Geodezia ta zemleustrij" [Syllabus of the studying discipline Foreign language for professional communication (English)" for students according to the educational program" Land Planning and Cadastre", specialty 193 "Geodesy and Land Planning"]. URL: http://ep.3.nuwn.edu.ua/18847

2. Grabovska, I. V. (2019). Metacommunicative contact-establishing topicalizing questions in modern English dialogic discourse. International repeating basic grammar, special terms and communicative clichés, it is aimed to be studied only by the advanced group students who had joint the community of future land managers after graduation from the profile colleges and who did not learn foreign language on the first course of studying at the Faculty of Land Management within the National University of Life and Environmental Sciences of Ukraine; 3) thematic filling of foreign language course for the second year bachelor's degree advanced group students in land management is similar to some topics to be studied by bachelor's degree senior students of other specialties too exampling specialty "Forestry and Horticulture" or "Mechanical Engineering" as well as the fourth-year students of specialty "Geodesy and Land Planning" as the future entrants of magistracy; 4) there are similar demands to fix and to represent the studying results during preparation to the attestation exam on the last lessons: to know basic questions and answers according to the course content, to know the structure of examination card, to know the stages of attestation exam, to be able to apply the got knowledge on practice and to deal with e-learn testing, be able to archive the results of works in the adequate folder; 5) in some cases there are similar types of lesson activities like noting unknown items, preparation, sending and oral defense of practical works, individual tasks, presentations, essays, participation in game, dialogues e-learn testing etc.; besides, the above named activities the second year students deal with $\epsilon B I$ workbooks filling, the work with $\epsilon B I$ manual and concluding own vocabulary too, such additional activities for the master degree students are writing annotations, theses, stand reports, business letters, etc. Perspectives of further investigation is description of the results of the further pedagogical observations to reveal gaps within the above named content curriculum and regarding the expediency of the unification of two blocks for second year students into one special block.

journal of philology. 10 (1), 38-41 DOI: http://dx.doi.org/10.31548/philolog2019.0 1.038

3. TNPU. (2020). Metodychni rekomendatsii do ukladannia sylabusiv [The guidelines to conclude syllables].URL:http://tnpu.edu.ua/about/public_inform/ upload/2020/metodychni_rekomendatsiji_sylabus.pdf

4. Yakushko, K. H. (2020). The categories of specialized vocabulary in the sphere of automation to develop students' foreign language communicative skills. Modern researches in philological sciences: collective monograph: Romania: North University Centre of Baia Mare, 427-448.DOI https://doi.org/10.30525/ 978-9934-588-37-2/25

5. Yakushko, K. H. (2019). Kurs: Anglijska mova Al sk [English course for advanced

(C) K. H. Yakushko, A. V. Polishchuk, L. V. Berezova

«International journal of philology» | «Міжнародний філологічний часопис» Vol. 12, № 2, 2021 
mechanical engineers]. URL: https://elearn.nubip. edu.ua/course/ view.php?id =723

6. Yakushko, K. H. (2020). Kurs: Anglijska mova GiZ [English course for Geodesy and Land planning]. URL: https://elearn.nubip.edu.ua/ course/ view.php?id=2316

7. Yakushko, K. H. (2020). Kurs: Dilova anglijska mova GiZ [Business English course for
Geodesy and Land planning ]. URL: https://elearn. nubip.edu.ua/ course /view.php?id=1032

8. Yakushko, K. H., Berezova, L. V. (2020). The search of psycholinguistic images for the technical terms on the professionally oriented English lessons. International journal of philology. 11 (2),135-139. DOI: http:// doi.org/10.31548/philology 2020.02.135

\title{
ТЕМАТИКА КУРСІВ ІНОЗЕМНОÏ МОВИ ДЛЯ СТАРШОКУРСНИКІВ СПЕЦІАЛЬНОСТІ «ГЕОДЕЗІЯ ТА ЗЕМЛЕУСТРІЙ» К. Г. Якушко, А. В. Поліщук, Л. В. Березова
}

\begin{abstract}
Анотація. Стаття дотична до проблеми тематичного наповнення навчальних планів через укладання силабусів та відповідного опису змістової структури плану, наприклад, вивчення іноземної мови як загального курсу іноземної мови за професійним спрямуванням або з діловим акцентом, або як підготовчого курсу до складання єдиного вступного іспиту з іноземної мови (ЄВІ) до магістратури. Основною метою статmі $\epsilon$ опис тематичного наповнення структури курсу іноземної мови для спеціальності «Геодезія та землеустрій» на подальщій стадії навчання на бакалавраті та на початковому етапі навчання у магістратурі. Суміжною метою статmі $\epsilon$ здійснення порівняльної характеристики тематичного наповнення відповідних силабусів на основі педагогічного спостереження 2019/2020р. Результатом дослідження є 5 висновків: 1) курс іноземної мови для першокурсників магістратури має, насамперед, на меті розвиток ділового мовлення поряд з розвитком загальнокомунікативних, профресійних $і$ наукових навичок та призначений для студентів усіх форм навчання за спеціальністю «Геодезія і землеустрій»; 2) курс іноземної мови для другокурсників бакалаврату спрямований більшою мірою на підготовку до складання ЄВІ до магістратури поряд з повторенням основ граматики, спеціалізованих термінів та комунікативних кліше та призначений для студентів тільки скороченого терміну навчання, які доєдналися до спільноти майбутніх землевпорядників після закінчення профрільних коледжів та не вивчали іноземну мову на першому курсі навчання на фракультеті землевпорядкування НУБіП України; 3) тематичне наповнення курсу іноземної мови для другокурсників бакалаврату суголосне частині тем, актуальних і для випускників бакалаврату інших напрямів підготовки (наприклад спеціальностей «Лісове та садово-паркове господарство» або «Агроінженерія») та для студентів четвертого курсу спеціальності "Геодезія $i$ землеустрій» як майбутніх абітурієнтів магістратури; 4) спільні вимоги до оформлення результатів навчання впродовж підготовки до іспиту на останніх заняттях: знати основні запитання та відповіді стосовно змістового контенту курсу, знати структуру екзаменаційного бланку, знати етапи проведення іспиту, вміти застосувати отримані знання на практиці через виконання пробного тесту, вміти заархівувати результати робіт у відповідній папці; 5) і студенти другого курсу бакалаврату, $і$ студенти першого курсу магістратури задіяні до роботи в електронних курсах, виконують такі типи роботи, як написання конспекту, укладання резюме, підготовка та усний захист практичних робіт й індивідуальних завдань, презентацій,обопільно беруть участь у ділових іграх, діалогах-дискусіях; при цьому для другого курсу на певних етапах додається ще й заповнення робочих зошитів ЄBI, робота з підручником ЗНО та розробка словника, а для магістрантів додаються такі види роботи, як написання анотації, тез, розробка стендової доповіді, написання ділового листа тощо. Перспективою досліджень є опис результатів подальших педагогічних спостережень змісту електронних курсі для слухачів вищої освіти з числа студентів технічних та агробіологічних спеціальностей різних напрямів підготовки.
\end{abstract}

Ключові слова: тематичне наповнення, змістова структура, курс вивчення іноземної мови, геодезія та землеустрій, студенти стариих курсів, бакалаврат, магістратура. 